\title{
Native and non-native species for dryland afforestation: bridging ecosystem integrity and livelihood support
}

\author{
Orna Reisman-Berman $^{1,2}$ (D) - Tamar Keasar ${ }^{3} \cdot$ Noemi Tel-Zur $^{1}$
}

Received: 23 December 2018 / Accepted: 18 November 2019/Published online: 11 December 2019

(C) The Author(s) 2019

\begin{abstract} community livelihoods. ecosystem services for humans. disrupt, ecological and socio-economic services. ensuing from them. We discuss the ecological context of this proposal.

\section{Handling Editor: Bruno Fady}

Contribution of the co-authors This article is a synthesis and each author contributed from her field of expertise. Orna Reisman-Berman contributed in the fields of forestry, dryland afforestation, and ecology. Tamar Keasar contributed in the fields of ecology, pollination ecology, and bee foraging. Noemi Tel-Zur contributed in the fields of reproductive biology and the biology of Ziziphus spp. All authors wrote and edited the manuscript.
\end{abstract}

- Key message We propose a silvicultural-ecological, participatory-based, conceptual framework to optimize the socioeconomicecological services provided by dryland afforestation, i.e. addressing the limited resources in arid areas while minimizing the harm to the environment. The framework applies the following criteria to select multifunctional tree species: (a) drought resistance, (b) minimal disruption of ecosystem integrity, and (c) maximization of ecosystem services, including supporting

- Context Dryland afforestation projects frequently aim to combine multiple ecological and economic benefits. Nevertheless, plant species for such projects are selected mainly to withstand aridity, while other important characteristics are neglected. This approach has resulted in planted forests that are drought-resistant, yet harm the natural ecosystem and provide inadequate

- Aims We suggest a comprehensive framework for species selection for dryland afforestation that would increase, rather than

- Methods To formulate a synthesis, we review and analyze past and current afforestation policies and the socio-ecological crises

- Results To increase afforestation services and to support human-community needs, both native and non-native woody species should be considered. The framework suggests experimental testing of candidate species for their compliance with the suggested species selection criteria. Furthermore, regional stakeholders are involved in evaluating, ranking, and prioritizing the candidate species according to experimental results and stakeholders' values and needs. We exemplify our approach by describing our ongoing research project, aimed to evaluate several native and exotic Ziziphus species in the Middle East region.

- Conclusion The employment of our proposed framework forms a novel community of native and non-native woody species.

Orna Reisman-Berman oreisman@bgu.ac.il

1 French Associates Institutes for Agriculture and Biotechnology of Drylands, J. Blaustein Institutes for Desert Research, Ben-Gurion University of the Negev, 84990 Sede-Boqer Campus, Israel

2 Department of Natural and Life Sciences, Open University of Israel, PO Box 808, 43107 Raanana, Israel

3 Department of Biology, University of Haifa (UH), Oranim, 36006 Tivon, Israel
Keywords Conceptual framework - Multi-functional forest . Invasive species $\cdot$ Forest participatory planning $\cdot$ Ecosystem services $\cdot$ Drought resistance

\section{Introduction}

Drylands are characterized by scarce water resources $(<\sim$ $500 \mathrm{~mm}$ ) annual rainfall, Aridity Index > 0.65 (UNEP 1992)), with a high spatial and temporal variability in precipitation that increases with aridity. Arid areas cover $40 \%$ of the world's earth and support $30 \%$ of its population. Dryland inhabitants consist the majority of the world's poor population, and as many as $16 \%$ of the inhabitants of drylands live in chronic poverty (http:// drylandsystems.cgiar.org). Unsustainable land use practices, adverse climatic conditions, and population increases in many dryland regions contribute to land degradation, which impairs ecosystem services and contributes to food insecurity, carbon 
emissions, and social and political instability (Yirdaw et al. 2017). These predicaments have fueled the action of afforestating, i.e., the formation of a novel tree ecosystem as one of the restoration tools to combat land degradation and decreased ecosystem services (Harris et al. 2006; Chazdon 2008). Accordingly, the socio-ecological aims of many dryland afforestation projects include conservation and regeneration of soil and biodiversity, water conservation, groundwater recharge, dust and flood prevention, and maintenance of a cool micro-climate. Some of the projects aim to produce food and timber, to generate recreation areas and even to create jobs (Mander et al. 2007; Nassauer and Opdam 2008; Scherr and McNeely 2008; Lovell and Johnston 2009; Chirwa and Mahamane 2017). The Great Green Wall for the Sahara and the Sahel Initiative, aimed to restore forest landscapes and degraded lands in Africa, is a pertinent example (Berrahmouni et al. 2014). Unfortunately, these goals have been only partially achieved. One of the main reasons for the lack of complete success lies in the species composition of the planted forests, which is the key to their effect on humans and the environment. Tree species for dryland afforestation were and still are selected mainly for drought tolerance and rapid growth and establishment (e.g., Ben Dov et al. 2001). Such a selection strategy ignores other biological characteristics of the trees and has severely damaged the integrity of some natural ecosystems, mainly due to tree invasiveness and habitat fragmentation.

While the pros and cons of afforestation of arid areas are currently under active discussion, it continues to be widely practiced. Recently, Yosef et al. (2018) demonstrated that largescale dryland afforestation in arid environments can potentially enhance carbon sequestration, moisture penetration, and precipitation, influencing areas larger than the actual afforestation. Those modeling results, which are based on previous empirical results (Rotenberg and Yakir 2010), produce a strong recommendation to further increase the scale of dryland afforestation.

This paper calls for a comprehensive framework for dryland afforestation that would increase, rather than disrupt, ecological as well as socio-economic services. We argue that afforestation in drylands should include species that sustainably support livelihoods, can be extensively managed, and pose minimal risk to the integrity of the natural ecosystem. Based on past and present socio-ecological crises, we suggest a process to select woody species for dryland afforestation that would form multifunctional forests. Similar agendas were recently suggested for large-scale forest restoration projects, aimed at climate change adaptation and mitigation worldwide, rather than rehabilitation of arid ecosystems (Stanturf et al. 2015, 2017).

\section{Ecological challenges and opportunities in dryland afforestation-past and present}

The need for careful land management in arid regions is exemplified by the history of afforestation in Middle Eastern drylands. Travelers in the 19th century described the vegetation in the area as dwarf shrublands with a few forest patches of Pinus halepensis Miller and Quercus calliprinos Webb (Paz 1979). These landscapes resulted from a long history of economic pressures and heavy grazing, which depleted the woody species populations of the native woodland and shrubland ecosystems (Pignatti 1983). As a result, the physiognomy of the woodland changed, triggering soil erosion and ecosystem degradation (Bottema et al. 1990; Lespez 2003). The degraded landscapes of the Middle East have thus motivated inhabitants throughout the region to establish large-scale afforestation projects attempting to reclaim and restore the ecosystems. Some major ecological crises ensued, owing to the traits of the tree species selected for these afforestation efforts. These crises include:

1. Altering of native plant communities by the invasion of afforestation species

The first risk associated with planted forests is the invasive spread of the planted species (Richardson 1998). The invasion and spread of a species depend both on the susceptibility of the environment to invasion (invasibility) (Lonsdale 1999) and on the traits associated with the species' ability to become invasive (species' invasiveness) (Goodwin et al. 1999). Non-native introduced species with long-lived seed banks and/or shoot resprouting abilities are hypothesized to persist in harsh environments and to eventually become invasive (Lawes et al. 2006). A well-known example is the introduced Australian acacia, Acacia saligna (Labill.) H. Wendl., which has established new populations outside planted areas. This significantly altered arid and semi-arid ecosystems over a wide geographical range (Wilson et al. 2011). Other examples of introduced invasive species include Eucalyptus spp. and Prosopis juliflora (Sw.) Dc. These species were planted in dryland afforestation projects in Africa, in the Middle East, and in arid zones around the Mediterranean basin, and their distribution has since extended into a wide range of ecosystems (Henderson 2001; Dufour-Dror 2012).

More recently, the spontaneous expansions of native species beyond their historical distribution range, or dramatic increases in their populations, have also been recognized as invasions. Such invasions often arise in response to human interventions, such as wildfire suppression, urbanization, or climate change (Carey et al. 2012; Valéry et al. 2013). A recent example is Pinus halepensis, native to the Eastern Mediterranean, which has spread from afforestations into ecosystems that the species does not inhabit naturally, including semi-arid grasslands, shrublands, and woodlands. The distance from the source population, precipitation, substrate type, woody vegetation density, and grazing pressure best explain $P$. halepensis' expansion success into new habitats 
(Osem et al. 2011; Sheffer et al. 2014). Fire, however, does not have a significant effect on pine invasions (Osem et al. 2011).

2. Contamination of the native gene pool

This is another aspect of human-mediated species movement that is only starting to receive attention (Rejmánek 2014). The introduction of alien species that are closely related to local ones may result in new geographic overlaps with the native species. In these cases, therefore, hybridization between native and non-native species could occur. Such hybridization events might introduce new alleles into the indigenous gene pool with further risks to the local genotypes and native populations (Wolf et al. 2001; Barbour et al. 2010). There are currently no clear policies or protocols to test for potential hybridizations between native local trees and introduced species that are close relatives (Flory and D'Antonio 2015).

3. Inhibited establishment of native species under the afforestation canopy

Drought-tolerant plants are traditionally considered suitable for dryland afforestation. Yet, some of these species, such as Eucalyptus spp. and Prosopis spp., pose an ecological risk because of their allelopathic traits. Such trees release phytotoxic compounds into the environment, e.g., volatile oils in E. camaldulensis (Verdeguer et al. 2009) or water-soluble phenols in P. juliflora (AlHumaid and Warrag 1998). These metabolites can strongly inhibit the germination of other plant species (Inderjit and Callaway 2003) or even the germination and establishment of congeneric species (Inderjit et al. 2008). In Middle East afforestations planted with Eucalyptus spp. or Prosopis spp., the establishment and further recolonization of native species under the afforestation canopy are strongly inhibited (Reisman-Berman et al. 2011). At the landscape scale, allelopathy in planted forests could interrupt vegetation landscape connectivity by impeding the dispersal and spread of native plant species through afforestation patches. This fragmentation of natural habitat patches could, in turn, restrict gene flow of native species (Honnay et al. 2002).

4. Changes in vegetation physiognomy, with potential ecosystem-level effects

Alteration of vegetation physiognomy, from a typical arid shrubland with sparse trees to patches of tall trees, may drastically affect ecosystem resource cycling and ecological networks. For example, planting tall and spaced trees ('savanization') in a desert afforestation project in Israel provided avian predators with perching and scouting points and thus increased their foraging efficiency. This, in turn, caused a decrease in lizard populations (Hawlena and Bouskila 2006). The transformation from shrub-dominated to tree-dominated landscapes in a semiarid area reduced both the productivity of the herbaceous species and the soil fertility beneath the canopies of the trees, as compared to the productivity and soil fertility under the shrub canopy in a native shrubland ecosystem (Paz-Kagan et al. 2016). The above examples emphasize the multidimensional response of an ecosystem to converting a shrubland into a forest.

\section{Social challenges of dryland afforestation}

Dryland afforestation programs should be designed not only to minimize ecological risks but also to provide multiple longterm benefits for local inhabitants. Increasing aridity and tree logging for fuel are the main factors causing land and forest degradation in natural dryland areas. Forest loss in these areas has been estimated to exceed $40 \%$ within four decades (De Waroux and Lambin 2012). Logging pressures are expected to increase even further, as the global need for wood is estimated to triple or even quadruple by 2050 (Fund for Nature 2011). These considerations point firmly to the need to plant and protect new trees for human benefit. In particular, in deprived areas, forests can provide food in the form of fruit and can also serve as a hunting habitat (Sunderlin et al. 2005). The introduction of merely a few productive fruit trees into subsistence farms can dramatically enhance household incomes (Neupane and Thapa 2001). One of the best examples of a tree species suitable for the provision of multiple ecosystem goods and services in drylands is Argan [Argania spinosa (L.) Skeels], which provides cattle fodder, wood for fiber and fuel, and seeds for the production of high-quality oil in southwestern Morocco. However, due to intensive exploitation and consecutive droughts, the species is under threat in its natural habitats (De Waroux and Lambin 2012).

In more prosperous countries, the utilization of forests changed from timber production at the industrial stage to a post-industrial stage, at which the forest is perceived as a multi-purpose functioning ecosystem (Sunderlin et al. 2005). Multifunctional forests support sustainable food provision, along with creation of jobs and additional provisioning and regulating ecosystem services (Lovell and Johnston 2009).

There are strong relationships between multi-functionality of the landscape, the involvement of the community in forest management, and the actual conservation of natural resources. These interactions can be optimized through 'participatory planning', namely, public participation in forest planning (Buchy and Hoverman 2000). The power of participatory planning is in the integration of local knowledge with science-based approaches (Agrawal and Gibson 1999). It has been advocated as a necessary step for any forest restoration project (Hanson et al. 2015). In North America and Europe, it often aims to sustain the forest as a functioning ecosystem that conserves biodiversity (Aerts and Honnay 
2011). In developing countries, participatory planning aims to manage and conserve natural stands and agroforests to provide basic food and regular income (German et al. 2006; Reij et al. 2009; Xu et al. 2012; Sacande and Berrahmouni 2016).

The advantages of participatory planning have been particularly well demonstrated in a study conducted in a rural semiarid region of Spain (García-Llorente et al. 2012). This study showed that the more multifunctional the landscapes, the more conservation support they received from the local communities. Accordingly, the conversion of multifunctional landscapes to mono-functional ones disturbed the capacity of rural areas to provide diverse ecosystem services and hence, reduced community support for their conservation.

Today, more and more reforestation and afforestation projects are aimed at providing multi-purpose functioning ecosystems (Rudel et al. 2010). Nevertheless, in practice, multifunctional participatory planning is more commonly being integrated into afforestation projects in wealthy communities than in deprived populations and in disadvantaged areas of the world. Thus, multifunctional afforestation in drylands still remains a formidable challenge (Lambin and Meyfroidt 2010; Wolfersberger et al. 2015).

\section{What is missing? A framework to maintain ecosystem integrity, increase afforestation services, and support community livelihood in drylands}

To reduce the ecological risks of afforestation projects, The Convention for Biological Diversity (http://www.cbd.int/forest/ tools.shtml) provided guidelines for forest planning and management. The guidelines recommend planting of native woody species, aiming at increasing the similarity between human-planted and native forests. We argue that in drylands, in particular, these guidelines are insufficient in the following aspects:

(1) We argue that it is cardinal to develop agendas and protocols to test and select woody species for dryland afforestation based both on their contribution to the local human communities and on their impacts on nearby ecosystems. We suggest that species selection processes should be fed from (a) lessons learnt from past forest crises and (b) the results of experiments, specifically designed to test the contribution and impact of candidate afforestation species in a specific dryland region.

(2) We claim that, in drylands, the exclusive use of native trees might decrease afforestation ecosystem services, in particular in supporting local community livelihoods, and that native species are not always optimal. Instead, we suggest that non-native species also be considered as afforestation candidates after they have been experimentally evaluated for potential ecological risks and services. It may be argued that planting native species could preclude environmental crises caused by the introduction of alien species (Hobbs et al. 2006). However, there are several scenarios for which this supposition is not true. First, native species can expand their distribution with afforestation activities and outcompete other species, as discussed above regarding Pinus halepensis. Second, native species are well adapted to the local environment, but when used in dryland forestry, they are sometimes planted at the margins of their ecological distribution and in degraded habitats, which could possibly lead to tree mortality (Dorman et al. 2015) with no regeneration (Osem et al. 2013). Third, native species do not always offer all the characteristics that are required of a multifunctional forest, especially in terms of livelihood support. Non-native species that are closely related to the native ones may often be more suitable in that they are likely to have both similar ecological suitability and performance and similar aesthetic and cultural values (Hodder and Bullock 1997), but can potentially provide extra benefits. Thus, the introduction of closely related species from abroad may address the important need for additional ecosystem services. Exotic species, closely genetically related to the native ones, should be introduced only if it is possible to avoid any spontaneous hybridization with their native relatives and further genetic contamination (Barbour et al. 2010; Carey et al. 2012). Additional aspects of invasiveness, such as resprouting, vegetative spread, and spontaneous establishment, need to be tested in the native and alien candidate trees, before they are planted in large-scale forest stands.

Non-native trees have been widely used to increase ecosystem services and support livelihoods, particularly in areas characterized by limited resources (Vilà and Hulme 2017). Their contribution to those aims has been lately reacknowledged. Yet, it is also clear that forestry programs often fail to harness the advantages of introduced species to a win-win situation with no or little negative effect (Witt 2017).

This means that there is a delicate balance between the desired spontaneous forest regeneration required to maintain forest sustainability and the "out of control" regeneration that can turn the non-native species to invasive ones. Our suggested framework addresses this challenge.

(3) We call for multifunctional afforestation. In the past few decades, planting of multifunctional woody species has slowly begun to receive attention within forestry projects that aim to enhance rural livelihoods (German et al. 2006; Chazdon 2008).

(4) We stress the need to integrate participatory planning in afforestation. We think that past and present afforestation projects have not paid sufficient attention to the needs 
and preferences of local inhabitants. The integration of stakeholders in planning of forest management has become a crucial element in modern silviculture, ecology, and other environmental disciplines (Lovell and Johnston 2009; Houehanou et al. 2011). Participatory planning of tree ecosystems has so far been applied to single-use forests, and a protocol for community involvement in the design of multi-functional afforestations is yet to be developed. The selection of tree species for multiple benefits, by a defined set of criteria, has been demonstrated only in a few instances and has not necessarily been performed for afforestation purposes but rather for genetic tree improvement (Franzel et al. 1996). Any program for participatory planning should be based on prioritization, a process in which multiple evaluation criteria are ranked and weighed (Barazani et al. 2008). A pioneering study on the selection of trees by a set of criteria was conducted by Reubens et al. (2011). In that study, trees were ranked for land rehabilitation by a multi-criteria decision-based approach. While an excellent starting point for multi-species afforestations, this study is limited in two respects: it is based on a metaanalysis of the scientific literature and therefore suffers from unavoidable knowledge gaps that have to be addressed experimentally. In addition, as the authors pointed out: "It is essential that such final assessment is made together with local stakeholders, particularly those user groups potentially vulnerable to land or tree use restrictions" (Reubens et al. 2011).

\section{The proposed framework}

To address the gaps described above, we suggest an integrative framework for selecting species assemblages for multifunctional and sustainable dryland afforestation (Fig. 1). First, we suggest three principal criteria for species selection. Those criteria are based on past and current socio-ecological silvicultural crises. Accordingly, the selected species should (a) withstand the arid environment, including compatibility with dryland soil conditions; (b) minimally risk and damage to ecosystem functions through invasiveness, cross hybridization, suppression of local species, and disruption of forest physiognomy; and (c) contribute to community livelihoods. Next, we suggest four steps that involve the selection and the evaluation of the species through a feedback process between the scientific, forest managerial, and the community stakeholders (Fig. 1):

Step 1: Surveying local trees and their closely genetically related non-local woody species over a wide ecogeographical region, to form a list of candidate species. These species should comply with the values, needs, experience, knowledge, and expectations of land owners, managers, and other stakeholders. The candidate non-local woody species should add value and enhance ecological services provided by the local species that currently thrive in the region or that used to flourish there historically. This step crystalizes specific benchmarks of the community beyond the principle criteria. However, it also requires the constant examination of evoking local crises and risks that should be included in the list of criteria. This step involves the academia and the whole range of stakeholders from the local community, forest managers, and practitioners.

Step 2: Testing the candidate native and non-native woody species experimentally, over a wide range of aridity conditions, for their compliance with the main and specific local criteria. We believe that the experimental approach will reduce knowledge gaps and facilitate region- and site-specific decision-making regarding the list of desired species for local drylands. This step involves the scientific community.

Step 3: Prioritizing the examined species according to the experimental results (step 2), the principal criteria and the community needs and values. This step involves both local communities and scientists.

Step 4: Long-term monitoring of the afforestation and the surrounding ecosystem and in situ feedback aimed at interactive adaptive management, with on-going feeding of information to the community, forest managers, and decision makers.

Step 1 concurs with the United Nations FAO's guidelines for restoration of degraded forests and landscapes in drylands, which stress the need to combine technical criteria with local preferences when selecting afforestation species (Berrahmouni et al. 2015a, b). Furthermore, the FAO guidelines emphasize assessment and monitoring of forest restoration projects as components of adaptive management, in agreement with step 4 of our framework.

The novelty of the proposed dryland afforestation framework is in developing a simple step-wise process that bridges scientific studies, social needs, and values shaped by stakeholders from the community, governmental organizations, and NGOs.

The innovation in the field of ecology resides in identifying candidate species that do not endanger ecosystem functioning and integrity. Such dangers may arise from the simple action of man-mediated species movement to form a novel or designed ecosystem. We distinguish between the risks of invasiveness, i.e., the spread of species from the afforestation to surrounding ecosystems and beyond, and the risks that are related to the afforestation as a novel ecosystem that interacts with its adjacent natural ecosystems. The latter category includes the risks of cross-pollination between the local and the planted species, allelopathy, and its effect on species movement through the 


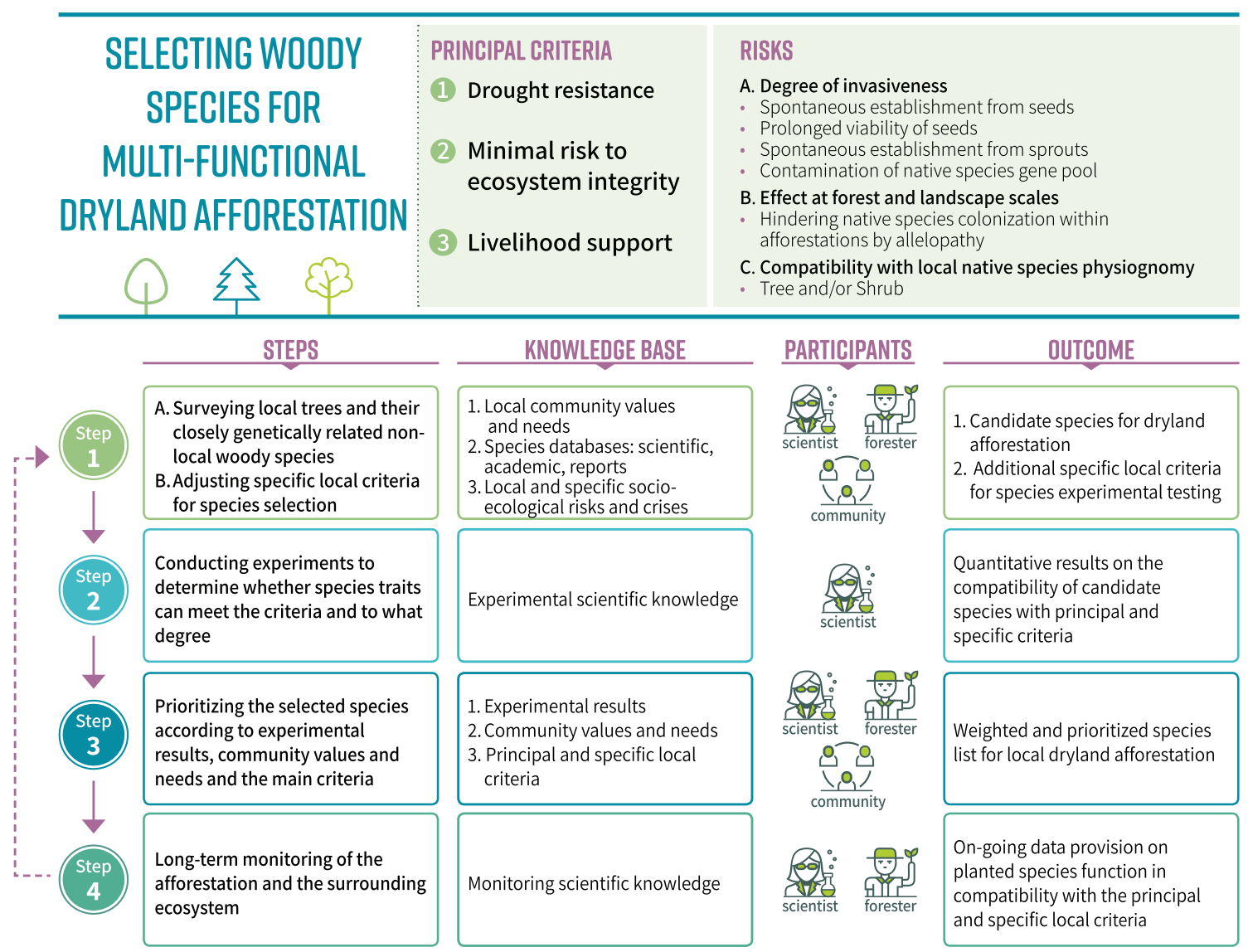

Fig. 1 Illustration of the suggested conceptual framework for selecting native and non-native woody species for multifunctional dryland afforestation. The framework suggests considering criteria and potential risks based on past and current socio-ecological silvicultural crises. The

forest; and the changes in the natural vegetation physiognomy that may occur with the introduction of afforestation.

Hereby, we illustrate the proposed framework by suggesting five species of the genus Ziziphus for dryland afforestation in the Middle East. Presently, various Ziziphus species are being planted in some dryland afforestation projects that aim to integrate native species (Bozzano et al. 2014). In other projects, Ziziphus species are introduced because of their contribution to provisioning ecosystem services (Owens and Lund 2009). We exemplify the proposed use of native and non-native trees by considering three species that are native to the region of the Middle East and two that are non-native.

\section{Ziziphus as a case study-biology and ecology of the candidate genus}

Species of the genus Ziziphus Mill. (Rhamnaceae) are spiny shrubs and small trees distributed in warm-temperate and subtropical regions throughout the Old and New Worlds (Islam and Simmons 2006). Several Ziziphus species are native to arid and semiarid ecosystems and are intrinsically adapted to process involves experimental testing and evaluation of the species through a feedback process between the scientific, forest managerial, and the community stakeholders

dry and hot climates. Therefore, they have excellent potential for dryland afforestation (Mizrahi and Nerd 1996). We focus on five promising species: Z. mauritiana Lam., Z. jujuba Mill., Z. spina-christi (L.) Desf., Z. lotus (L.) Lam., and Z. nummularia (Burm.). These five species provide multiple and complementary benefits (Outlaw et al. 2002; Saied et al. 2008; Pandey et al. 2010), as shown in Table 1. They have the potential to satisfy some of the suggested criteria for dryland afforestation: Z. spina-christi, Z. lotus, and Z. nummularia are native to the region. $Z$. lotus is a shrub and therefore provides an additional advantage by fitting into the physiognomy of dryland shrublands. Z. mauritiana and Z. jujuba are nonnative to the region, originating in the Far East and central Asia, respectively. However, they provide additional livelihood-supporting resources, which include attractive edible fruits and complemental foraging resources for honeybees throughout the dry season (Vashishtha 1997; Pareek 2001; Outlaw et al. 2002; Azam-Ali et al. 2006; Haddad et al. 2008; Pandey et al. 2010). The berry fruits falling on the ground also contribute to soil fertility, as was demonstrated in Z. mauritiana (Singh et al. 2012) and Z. spina-christi (Tessema and Belay 2017) in drylands savannas. Improved 


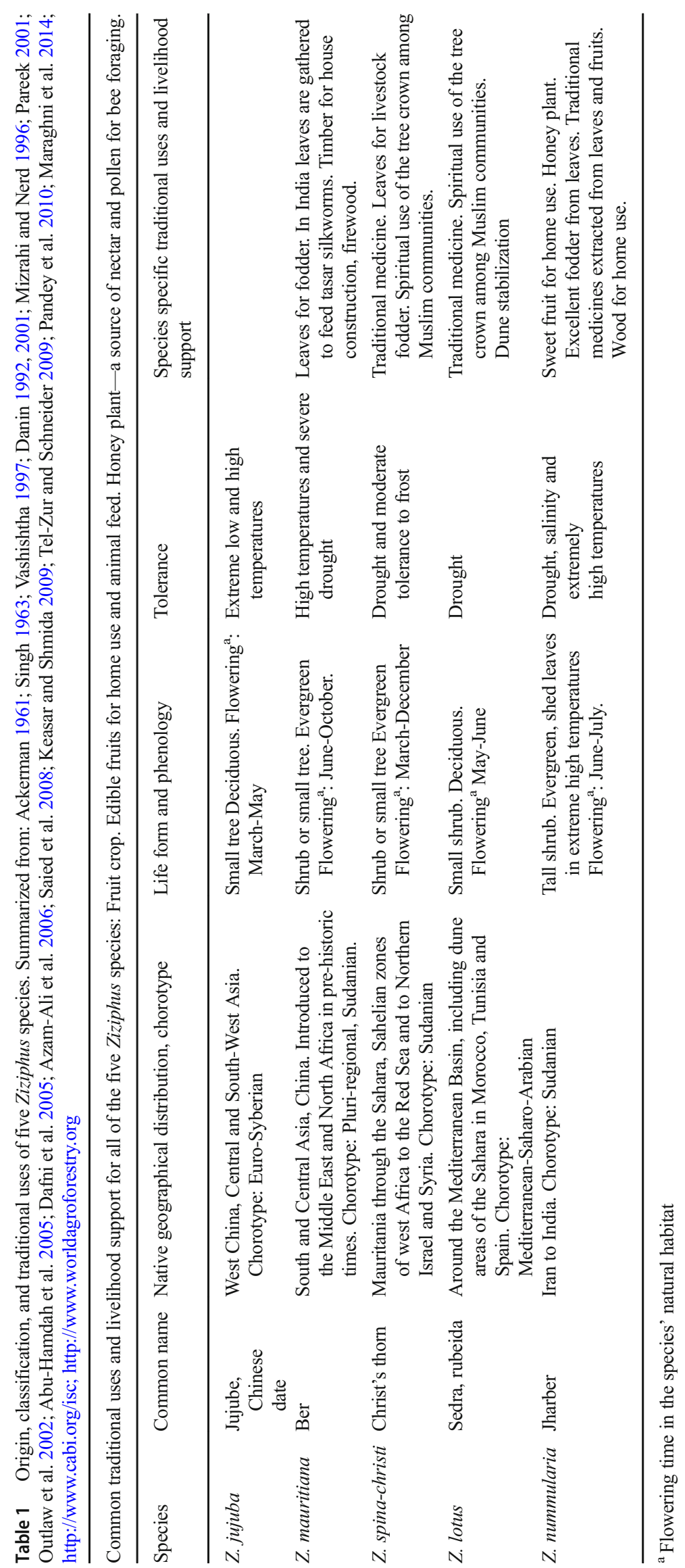


soil fertility may, in turn, result in increased herbaceous biomass and species richness under the canopy (Tessema and Belay 2017). Thus, planting these species mixed with other dryland afforestation species is expected to promote multifunctionality by combining drought resistance with livelihood support.

\section{A framework to integrate Ziziphus into a multi-functional afforestation}

To exemplify the framework, we consider the three principal criteria and risks, starting with an already defined list of species (step 1, Fig. 1). Therefore, we focus here on step 2-the experimental step of our suggested framework. This step tests the woody species' traits according to a set of socio-ecological criteria (Fig. 1). We pose a series of questions and experiments to address them, to be investigated for each criterion (Table 2). The timeframe of the experiments ranges 1-3 years, followed by in situ long-term monitoring at the afforestation site.

\subsection{Criterion 1: drought resistance}

Drought resistance is a complex of mechanisms and is difficult to assess by a single measure. Rather, it requires a set of developmental and physiological experiments that reveal the response of a species under specific conditions. To date, some studies have shown drought tolerance in Z. mauritiana (Clifford et al. 1998) and Z. jujuba (Cruz et al. 2012). Our suggested research questions include: which species develop and reproduce best under drought conditions? Does increased water availability improve the performance of the species and how is plant performance related to its drought tolerance? Is there a tradeoff between drought tolerance and the provisioning traits? To answer these questions candidate Ziziphus species should be grown in experimental plots, where their survival, development, and physiological performance are monitored.

\subsection{Criterion 2: minimizing the risk to ecosystem integrity}

Here, we focus on four features of ecosystem integrity disruption: invasion potential, hybridization and gene-pool contamination, allelopathy, and interference with the physiognomy of the local native vegetation. Up-to-date observations and monitoring of $Z$. mauritiana show that the species is invasive in some hot and humid countries but not in dry climate countries (CABI https://www.cabi.org/isc/datasheet/57556). We ask what is the ecosystem invasibility, i.e., to what extent are drylands sensitive to Ziziphus invasion? Simultaneously, we ask whether Ziziphus can become invasive? Are Ziziphus seeds viable for long periods, generating risks of invasion by spontaneous establishment, in particular in arid environments? Can establishment from resprouting shoots be limited under drought conditions? Can accumulated runoff in specific areas promote sprout establishment? These questions can be answered by an array of experiments that include seed burial trials in natural dryland ecosystems, tests of seed-bank viability, spontaneous establishment from seeds and resprouting, and general monitoring of vegetative development.

An additional set of experiments should evaluate the potential of the tree species to hybridize with local native species. We hypothesize that there might be also some risk of hybridization among the candidate Ziziphus species, as there is some overlap in the flowering seasons and spatial distributions of Z. spina-christi, Z. jujuba and Z. mauritiana (Asatryan and Tel-Zur 2014). Reciprocal interspecific artificial crossing between $Z$. spina-christi and Z. mauritiana, as well as between $Z$. jujuba and Z. spina-christi, resulted in the formation of viable seeds (Asatryan and Tel-Zur 2014). Z. nummularia also overlaps with these three species in blooming season (Feinbrun-Dothan and Danin 1991), hence could potentially hybridize with them if planted together. The major experimental question is whether any gene flow occurs among species, resulting in gene contamination and/or the establishment of interspecific hybrids. Experiments that involve hand-cross pollination among species, monitoring of fruit setting, and embryo viability are needed to test this question.
Table 2 Examples for experiments to evaluate Ziziphus spp. suitability for dryland afforestation

\begin{tabular}{|c|c|c|}
\hline Criterion & Experimental manipulation & Measure category \\
\hline $\begin{array}{l}\text { Drought } \\
\text { resistance }\end{array}$ & Water availability & $\begin{array}{l}\text { Plant survival and growth rate, flower and fruit production, } \\
\text { morphological and physiological signs of wilting }\end{array}$ \\
\hline \multirow{4}{*}{$\begin{array}{l}\text { Minimizing } \\
\text { ecological risk }\end{array}$} & Seed burial experiments & Seed viability, germinability \\
\hline & Time from seed dispersal & Seed viability, germinability \\
\hline & Water availability & Resprouting, germinability \\
\hline & Cross-pollination & Fruit set, embryo viability, hybrid seed germination \\
\hline $\begin{array}{l}\text { Livelihood } \\
\text { support }\end{array}$ & Introduction of honeybees & Honey production, foraging preferences, fruit yield \\
\hline
\end{tabular}


In testing for allelopathy, we ask: Do the leaves and fruits of the candidate species inhibit the germination, growth and survival of dryland species? Do they affect soil chemistry? Are allelopathic effects influenced by precipitation levels? Here simple bioassay experiments can be conducted under greenhouse and field conditions.

Finally, the changes in plant physiognomy as a result of afforestation and their ecosystem-level effects are the most difficult to measure. Using Ziziphus species as a case study, we ask: How will afforestation with Ziziphus trees affect ecosystem integrity, compared to afforestation with Ziziphus shrubs (Z. lotus), in particular where the natural vegetation of the arid environment has a shrubland physiognomy? This requires long-term monitoring of plots in afforestations and in the surrounding local ecosystem. Various measures of ecosystem functions should be recorded, including species biodiversity, food web structure and mineral cycling. Experiments of this kind are long-term, and thus unlikely to provide shorterterm insights for forest planning. Nevertheless, we believe that such experiments are essential and must be accompanied by adaptive management. To the best of our knowledge, compatibility of the architecture of introduced plant species with the physiognomy of local species has not been comprehensively studied in an ecological context.

\subsection{Criterion 3: livelihood support}

Ziziphus spp. flowers are an important source of nectar for high-quality honey production, and the fruits of some species are edible, providing potential sources of income for rural people (Table 1). Experiments should therefore test whether honeybees have preferences among Ziziphus species, and whether Ziziphus spp. nectar and pollen can adequately support the bees. Other experiments should focus on fruit yield and leaf biomass under dryland conditions.

\section{Discussion: wider implications}

\subsection{What constitutes a good species assemblage in planted forests?}

The use of non-native species to complement native trees in dryland afforestation is a contentious aspect of our proposed framework. The issue of non-local species becomes particularly thorny when considering afforestation projects aimed at ecosystem restoration and reclamation, i.e., forming plantations that highly resemble natural forests or the native plant community (Barlow et al. 2007). In this section, we briefly discuss a large body of recent ecological research, which maintains that human modifications of natural plant communities are inevitable and sometimes even ecologically beneficial. These ideas can provide a theoretical justification for combining local and alien trees in sustainable planted desert forests.

Views on plant species compositions have developed from a rigid structure of plant communities (Clements 1916) to a random species assemblage, presented by Hubbell (2001) as the Neutral Theory that unifies theories of biodiversity and biogeography. According to this view, species establishment is driven by random processes, and the diversity and distribution of plant communities represent the outcome of random birth, death, dispersal, and speciation events. Currently, the neutral theory is playing an increasingly central role in the planning of species assemblages and in predicting restoration outcomes within the discipline of restoration ecology (Fukami et al. 2005; Hector et al. 2011; Barnes et al. 2014). This theory allows for considerable variability in the composition of species planted for habitat restoration, as would be expected in a natural community governed by stochastic processes.

Additional views on the desirable assemblage of species in restored habitats include Rosenzweig's (2003) reconciliation ecology, which sees an opportunity in redesigning anthropogenic habitats, allowing the coexistence of broad assemblages of native and exotic species. Along similar lines, Hobbs et al. (2011) have stressed that restoration projects cannot turn the clock back to reconstruct pristine ecosystems, and therefore carefully thought out interventions are needed. This point of view can be particularly relevant to dryland forests, which have often been managed and exploited by humans during millennia for various provisioning services such as wood, fodder and fruit (Yirdaw et al. 2017; Berrahmouni et al. 2015a, b). Defining a "natural" state in such forest or savanna ecosystems might be misleading. The need for a thorough experimental approach, embedded in adaptive management, is termed "intervention ecology" (Hobbs et al. 2011), an approach that fits well with our proposed framework. Within this field we stress both the needs for an experimental approach and for adaptive management. Moreover, we follow the essence of this approach, which suggests that effective interventions should take into account the social and cultural history of the sites to be managed, together with current societal needs (Hobbs et al. 2011). We acknowledge that our framework also carries a price tag - the extra time and expenses needed for experiments, adaptive management, and stakeholder involvement.

We must thus ask: What are the implications of these theories for the selection of species assemblages for afforestation? Forest ecologists still do not know whether the selection of species assemblages that are comprised of the natural species community would recreate an ecosystem that maximizes ecosystem services. This uncertainty is reflected in the ongoing debate on "assisted migration," namely, translocation of trees outside their natural geographic distribution to reduce extinction risks due to climate change (Hewitt et al. 2011; Pedlar et al. 2012). Opponents point to risks of invasions (Mueller and Hellmann 2008) and the lack of sufficient 
understanding of the impacts of the introduced species (Ricciardi and Simberloff 2009). Supporters of this strategy, on the other hand, argue that native ecological communities cannot be conserved or maintained in the face of rapid anthropogenic change, thereby justifying active translocation of climate-endangered plants (Thomas 2011). Both proponents and critics agree that the sharp distinction between natural and novel ecosystems is becoming blurred in the era of global warming. By analogy, sustainable forestry in humandominated drylands may require species assemblages that differ from those of the native local woody species communities.

A few studies have investigated the role of natural vs. planted forest stands as providers of ecosystem services. Overall, studies on restoration projects have demonstrated a strong correlation between the increase in biodiversity and the gain of ecosystem services (Benayas et al. 2009). Barlow et al. (2007) have shown that primary forests have irreplaceable value in supporting biodiversity, although exotic tree plantations can provide complementary conservation services to those provided by natural stands. These findings were supported by Bremer and Farley (2010), who suggested that plantations best conserve biodiversity when they are established on degraded lands, rather than in natural ecosystems such as forests, grasslands, or shrublands. This is because man-made afforestations support biodiversity more effectively than degraded areas, but less well than natural ecosystems. Other studies have demonstrated that even systems based solely on exotic trees, such as agroforestry systems, maintain high species diversity when properly managed. Such afforestations can therefore play an important role in biodiversity conservation in human-dominated landscapes (Bhagwat and Willis 2008). It has also been recommended that the usefulness of diverse species assemblages with various traits be tested as a sustainable forest management strategy (Garnier and Navas 2012). The underlying rationale is that mixed diverse forests are more resistant to disturbances than single-species forests (Vilà et al. 2007). This approach complies with the restoration recommendations developed by Harris et al. (2006). These authors warn that by insisting on the exclusive use of local plant material (species/population/provenance), we may be consigning restoration projects to a genetic dead end, which does not allow for rapid adaptation to changing environments in the era of climate change.

To conclude, taken together, the above-described studies and concepts form a framework that applies ecological principles to arid zone afforestation. This framework is based on the conventional wisdom that the species assemblages chosen should resemble the natural plant communities. However, the details of the construction of the species assemblages may vary along a gradient from 'natural' to 'no-analog' (Jackson and Hobbs 2009) or 'novel' assemblages (Hobbs et al. 2006), with a decreasing affinity for the historical geographical distribution of the species (Seddon 2010). In practice, this conceptual gradient widens the range of selected species to a more diverse one that includes both native and non-native species. Integrating alien species in dryland afforestation projects, after careful experimental testing for ecological compatibility, may indeed complement the ecosystem services provided by native species. We can envisage a continuum starting at no intervention in the natural ecosystem (wild) through restored ecosystems, via afforestation, through more intensive agroforestry systems up to an extensive coppice, industrial forest, or an orchard ecosystem. Our framework offers an ecosystem designed to be an extensively managed, livelihood-supporting afforestation, somewhere between afforestation and agroforestry along this continuum.

Adapting a new framework for afforestation in drylands is mandate in the era of climate change, desertification and increased poverty in arid areas. All of these call for an integrative afforestation framework that would bridge between ecosystem integrity and livelihoods.

Acknowledgments We thank Profs. Alon Tal, Daniel Orenstein, and Eric Higgs for valuable comments on the manuscript. We thank Dr. U. Zurgil, Mr. J. Mouyal, and Mr. S. Feingold for technical assistance.

Statement on data availability Data sharing not applicable to this article as no datasets were generated or analysed during the current study.

Funding This work was supported by funding provided by USAIDMERC Program [grant number TA-MOU-12-M32-021].

\section{Compliance with ethical standards}

Conflict of interest The authors declare that they have no conflict of interest.

Open Access This article is licensed under a Creative Commons Attribution 4.0 International License, which permits use, sharing, adaptation, distribution and reproduction in any medium or format, as long as you give appropriate credit to the original author(s) and the source, provide a link to the Creative Commons licence, and indicate if changes were made. The images or other third party material in this article are included in the article's Creative Commons licence, unless indicated otherwise in a credit line to the material. If material is not included in the article's Creative Commons licence and your intended use is not permitted by statutory regulation or exceeds the permitted use, you will need to obtain permission directly from the copyright holder. To view a copy of this licence, visit http://creativecommons.org/licenses/by/4.0/.

\section{References}

Abu-Hamdah S, Afifi FU, Shehadeh M, Khalid S (2005) Simple qualitycontrol procedures for selected medicinal plants commonly used in Jordan. Pharm Biol 43:1-7. https://doi.org/10.1080/ 13880200590903228

Ackerman WL (1961) Flowering, pollination, self-sterility and seed development of Chinese Jujube. J Am Soc Hortic Sci 77:265-269

Aerts R, Honnay O (2011) Forest restoration, biodiversity and ecosystem functioning. BMC Ecol 11:29. https://doi.org/10.1186/ 1472-6785-11-29 
Agrawal A, Gibson CC (1999) Enchantment and disenchantment: the role of community in natural resource conservation. World Dev 27:629-649. https://doi.org/10.1016/S0305-750X(98)00161-2

Al-Humaid AI, Warrag MOA (1998) Allelopathic effects of mesquite (Prosopis juliflora) foliage on seed germination and seedling growth of bermudagrass (Cynodon dactylon). J Arid Environ 38:237-243

Asatryan A, Tel-Zur N (2014) Intraspecific and interspecific crossability in three Ziziphus species (Rhamnaceae). Genet Resour Crop Evol 61:215-233. https://doi.org/10.1007/s10722-013-0027-8

Azam-Ali S, Bonkoungou E, Bowe C, de Kock C, Godara A, Williams JT (2006) Ber and other jujubes. In: Williams et al. (Eds.), International Centre for Underutilized Crops, Southampton

Barazani O, Perevolotsky A, Hadas R (2008) A problem of the rich: prioritizing local plant genetic resources for ex situ conservation in Israel. Biol Conserv 141:596-600. https://doi.org/10.1016/j.biocon. 2007.10.014

Barbour RC, Wise SL, McKinnon GE, Vaillancourt RE, Williamson GJ, Potts BM (2010) The potential for gene flow from exotic eucalypt plantations into Australia's rare native eucalypts. Forest Ecol Manag 260:2079-2087. https://doi.org/10.1016/j.foreco.2010.08.049

Barlow J et al (2007) Quantifying the biodiversity value of tropical primary, secondary, and plantation forests. Proc Natl Acad Sci 104: 18555-18560. https://doi.org/10.1073/pnas.0703333104

Barnes AD, Emberson RM, Krell FT, Didham RK (2014) The role of species traits in mediating functional recovery during matrix restoration. PLoS One 9(12):e115385. https://doi.org/10.1371/journal. pone. 0115385

Ben Dov Y, Forti M, Pauker R, Aronson JA, Pasternak D (2001) Introduction and selection of drought and salt tolerant plants for afforestation and landscaping in arid lands. In: Pasternak D, Schlissel A (eds). Combating desertification with plants. Springer, pp. 121-148. doi:https://doi.org/10.1007/978-1-4615-1327-8 12

Benayas JMR, Newton AC, Diaz A, Bullock JM (2009) Enhancement of biodiversity and ecosystem services by ecological restoration: a meta-analysis. Science 325:1121-1124. https://doi.org/10.1126/ science. 1172460

Berrahmouni N, Tapsoba F, Berte CJ (2014) The great green wall for the Sahara and the Sahel initiative: building resilient landscapes in African drylands. In: Bozzano M, Jalonen R, Thomas E, Boshier D, Gallo L, Cavers S, Bordács S, Smith P, Loo J (eds) Genetic considerations in ecosystem restoration using native tree species. State of the world's forest genetic resources-thematic study. FAO, Rome

Berrahmouni N, Parfondry M, Regato P, Sarre A (2015a) Restoration of degraded forests and landscapes in drylands: guidelines and way forward. Unasylva 66:37-43

Berrahmouni N, Regato P, Parfondry M (2015b) Global guidelines for the restoration of degraded forests and landscapes in drylands. Building resilience and benefiting livehoods FAO Forestry paper 175 . FAO, Rome

Bhagwat SA, Willis KJ (2008) RSPO principles and criteria for sustainable palm oil production. Conserv Biol 22:1368-1370

Bottema S, Entjes-Nieborg G, van Zeist W (1990) Man's role in the shaping of the Eastern Mediterranean landscape. CRC Press, Groningen

Bozzano M, Jalonen R, Thomas E, Boshier D, Gallo L, Cavers S, Bordács S, Smith P, Loo J (2014) Genetic considerations in ecosystem restoration using native tree species. State of the World's Forest Genetic Resources - Thematic Study. FAO/Bioversity International pp. 281 ISBN 978-92-5-108469-4

Bremer LL, Farley KA (2010) Does plantation forestry restore biodiversity or create green deserts? A synthesis of the effects of land-use transitions on plant species richness. Biodivers Conserv 19:38933915. https://doi.org/10.1007/s10531-010-9936-4

Buchy M, Hoverman S (2000) Understanding public participation in forest planning: a review. Forest Policy Econ 1:15-25. https://doi. org/10.1016/S1389-9341(00)00006-X
Carey MP, Sanderson BL, Barnas KA, Olden JD (2012) Native invaderschallenges for science, management, policy, and society. Front Ecol Environ 10:373-381. https://doi.org/10.1890/110060

Chazdon RL (2008) Beyond deforestation: restoring forests and ecosystem services on degraded lands. Science 320:1458-1460. https:// doi.org/10.1126/science. 1155365

Chirwa PW, Mahamane L (2017) Overview of restoration and management practices in the degraded landscapes of the Sahelian and dryland forests and woodlands of East and southern Africa. Southern Forests 79:87-94

Clements FE (1916) Plant succession: an analysis of the development of vegetation. Carnegie Institution of Washington Publication Sciences 242:1-512. https://doi.org/10.5962/bhl.title.56234

Clifford SC, Arndt SK, Corlett JE, Joshi S, Sankhla N, Popp M, Jones HG (1998) The role of solute accumulation, osmotic adjustment and changes in cell wall elasticity in drought tolerance in Ziziphus mauritiana (Lamk). J Exp Bot 49:967-977. https://doi.org/10. 1093/jxb/49.323.967

Cruz ZN, Rodriguez P, Galindo A, Torrecillas E, Ondono S, Mellisho CD, Torrecillas A (2012) Leaf mechanisms for drought resistance in Zizyphus jujuba trees. Plant Sci 197:77-83. https://doi.org/10.1016/ j.plantsci.2012.09.006

Dafni A, Levy S, Lev E (2005) The ethnobotany of Christ's Thorn jujube (Ziziphus spina-christi) in Israel. J Ethonobiol Ethnomed 1:1-11. https://doi.org/10.1186/1746-4269-1-8

Danin A (1992) Flora and vegetation of Israel and adjacent areas. Bocconea 3:18-42

Danin A (2001) Near East ecosystems, plant diversity. In: Levin S (ed) Encyclopedia of Biodiversity. W. Junk, Publishers. Academic Press. 4:353-364. Chap 7, pp. 129-158

De Waroux YL, Lambin EF (2012) Monitoring degradation in arid and semi-arid forests and woodlands: the case of the argan woodlands (Morocco). Appl Geogr 32:777-786. https://doi.org/10.1016/j. apgeog.2011.08.005

Dorman M, Svoray T, Perevolotsky A, Moshe Y, Sarris D (2015) What determines tree mortality in dry environments? a multi-perspective approach. Ecol Appl 25:1054-1071. https://doi.org/10.1890/140698.1

Dufour-Dror JM (2012) Alien invasive plants in Israel. The Middle East Nature Conservation Promotion Association. Gefen Publishing, Jerusalem, pp 213

Feinbrun-Dothan N, Danin A (1991) Analytical flora of Eretz-Israel. Cana Publishing House Ltd., Jerusalem (in Hebrew)

Flory SL, D'Antonio CM (2015) Taking the long view on the ecological effects of plant invasions. Am J Bot 102:817-818. https://doi.org/ 10.3732/ajb. 1500105

Franzel S, Jaenicke H, Janssen W (1996) Choosing the right trees: setting priorities for multipurpose tree improvement. ISNAR Research Report No. 8. The Hague: International Service for National Agricultural Research

Fund for Nature (2011) The Living forest report. Gland, Switzerland. https://wwf.panda.org

Fukami T, Bezemer TM, Mortimer SR, van der Putten WH (2005) Species divergence and trait convergence in experimental plant community assembly. Ecol Lett 8:1283-1290. https://doi.org/10. 1111/j.1461-0248.2005.00829.x

García-Llorente M, Martín-López B, Iniesta-Arandia I, López-Santiago CA, Aguilera PA, Montes C (2012) The role of multi-functionality in social preferences toward semi-arid rural landscapes: an ecosystem service approach. Environ Sci Pol 19:136-146. https://doi.org/ 10.1016/j.envsci.2012.01.006

Garnier E, Navas ML (2012) A trait-based approach to comparative functional plant ecology: concepts, methods and applications for agroecology. A review. Agron Sustain Dev 32:365-399. https://doi.org/ 10.1007/s13593-011-0036-y 
German LA, Kidane B, Shemdoe R (2006) Social and environmental trade-offs in tree species selection: a methodology for identifying niche incompatibilities in agroforestry. Environ Dev Sustain 8:535552. https://doi.org/10.1007/s10668-006-9054-3

Goodwin BJ, McAllister AJ, Fahrig L (1999) Predicting invasiveness of plant species based on biological information. Conserv Biol 13:422426. https://doi.org/10.1046/j.1523-1739.1999.013002422.x

Haddad N, de Miranda JR, Bataena A (2008) Discovery of Apis florea in Aqaba, Jordan. J Apic Res 47:172-173

Hanson C, Buckinham K, DeWitt S, Laestadius L (2015) The restoration diagnostic. A method for developing forest landscape restoration strategies by rapidly assessing the status of key success factors. World Resources Institute, Washington, DC

Harris JA, Hobbs RJ, Higgs E, Aronson JAF (2006) Ecological restoration and global climate change. Restor Ecol 14:170-176

Hawlena D, Bouskila A (2006) Land management practices for combatting desertification cause species replacement of desert lizards. J Appl Ecol 43:701-709. https://doi.org/10.1111/j.1365-2664.2006. 01177.x

Hector A, Philipson C, Sener P, Champagne J, Dzulkifli D, O'Brien M, Snaddon JL, Ulok P, Weilenmann M, Reynolds G, Godfray HCJ (2011) The Sabah biodiversity experiment: a long-term test of the role of tree diversity in restoring tropical forest structure and functioning. Philos Trans R Soc B-Biol Sci 366:3303-3315. https://doi. org/10.1098/stb.2011.0094

Henderson L (2001) Alien weeds and invasive plants: a complete guide to declared weeds and invadors in South Africa. Plant Protection Research Institute, ARC LNR. Handbook 12, p 300

Hewitt N, Klenk N, Smith AL, Bazely DR, Yan N, Wood S, MacLellan JI, Lipsig-Mumme C, Henriques I (2011) Taking stock of the assisted migration debate. Biol Conserv 144:2560-2572. https:// doi.org/10.1016/j.biocon.2011.04.031

Hobbs RJ et al (2006) Novel ecosystems: theoretical and management aspects of the new ecological world order. Glob Ecol Biogeogr 15: 1-7. https://doi.org/10.1111/j.1466-822X.2006.00212.x

Hobbs RJ, Hallett LM, Ehrlich PR, Mooney HA (2011) Intervention ecology: applying ecological science in the twenty-first century. BioScience 61:442-450. https://doi.org/10.1525/bio.2011.61.6.6

Hodder KH, Bullock JM (1997) Translocations of native species in the UK: implications for biodiversity. J Appl Ecol 34:547-565. https:// doi.org/10.2307/2404906

Honnay O, Verheyen K, Butaye J, Jacquemyn H, Bossuyt B, Hermy M (2002) Possible effects of habitat fragmentation and climate change on the range of forest plant species. Ecol Lett 5:525-530. https://doi. org/10.1046/j.1461-0248.2002.00346.x

Houehanou TD, Assogbadjo AE, Kakaï RG, Houinato M, Sinsin B (2011) Valuation of local preferred uses and traditional ecological knowledge in relation to three multipurpose tree species in Benin (West Africa). For Policy Econ 13:554-562. https://doi.org/10. 1016/j.forpol.2011.05.013

Hubbell SP (2001) The unified neutral theory of biodiversity and biogeography. Monogr Pop Biol 32:i-xiv, 1-375

Inderjit, Callaway RM (2003) Experimental designs for the study of allelopathy. Plant Soil 256:1-11

Inderjit, Seastedt TR, Callaway RM, Pollock J, Kaur J (2008) Allelopathy and plant invasions: traditional, congeneric, and bio-geographical approaches. Biol Invasions 10:875-890. https://doi.org/10.1007/ s10530-008-9239-9

Islam MB, Simmons MP (2006) A thorny dilemma: testing alternative intrageneric classifications within Ziziphus (Rhamnacea). Syst Bot 31:826-842. https://doi.org/10.1600/036364406779695997

Jackson ST, Hobbs RJ (2009) Ecological restoration in the light of ecological history. Science 325:567-569. https://doi.org/10.1126/ science. 1172977
Keasar T, Shmida A (2009) An evaluation of Israeli forestry trees and shrubs as potential forage plants for bees. Isr J Plant Sci 57:49-64. https://doi.org/10.1560/IJPS.57.1-2.49

Lambin EF, Meyfroidt P (2010) Land use transitions: socio-ecological feedback versus socio-economic change. Land Use Policy 27:108118. https://doi.org/10.1016/j.landusepol.2009.09.003

Lawes RA, Murphy HT, Grice AC (2006) Comparing agglomerative clustering and three weed classification frameworks to assess the invasiveness of alien species across spatial scales. Divers Distrib 12:633-644. https://doi.org/10.1111/j.1472-4642.2006.00291.x

Lespez L (2003) Geomorphic responses to long-term land use changes in Eastern Macedonia (Greece). Catena 51:181-208. https://doi.org/ 10.1016/S0341-8162(02)00164-9

Lonsdale WM (1999) Global patterns of plant invasions and the concept of invasibility. Ecology 80:1522-1536. https://doi.org/10.1890/ 0012-9658(1999)080[1522:GPOPIA]2.0.CO;2

Lovell ST, Johnston DM (2009) Creating multifunctional landscapes: how can the field of ecology inform the design of the landscape? Front Ecol Environ 7:212-220. https://doi.org/10.1890/070178

Mander U, Helming K, Wiggering H (2007) Multifunctional land use. In: Mander U et al (eds) Multifunctional land use: meeting future demands for landscape goods and services. Springer, Berlin, pp 1-13. https://doi.org/10.1007/978-3-540-36763-5 1

Maraghni M, Gorai M, Neffati M, Van Labeke MC (2014) Differential responses to drought stress in leaves and roots of wild jujube, Ziziphus lotus. Acta Physiol Plant 36:945-953. https://doi.org/10. 1007/s11738-013-1473-9

Mizrahi Y, Nerd A (1996) New crops as a possible solution for the troubled Israeli export market. In: Janick J (ed) Progress in New Crops. ASHS Press, Alexandria, pp 37-45

Mueller JM, Hellmann JJ (2008) An assessment of invasion risk from assisted migration. Conserv Biol 22:562-567. https://doi.org/10. $1111 / j .1523-1739.2008 .00952 . x$

Nassauer JI, Opdam P (2008) Design in science: extending the landscape ecology paradigm. Landsc Ecol 23:633-644. https://doi.org/10. 1007/s10980-008-9226-7

Neupane RP, Thapa GB (2001) Impact of agroforestry intervention on soil fertility and farm income under the subsistence farming system of the middle hills, Nepal. Agric Ecosyst Environ 84:157-167. https://doi.org/10.1016/S0167-8809(00)00203-6

Osem Y, Lavi AA, Rosenfeld A (2011) Colonization of Pinus halepensis in Mediterranean habitats: Consequences of afforestation, grazing and fire. Biol Invasions 13:485-498. https://doi.org/10.1007/ s10530-010-9843-3

Osem Y, Yavlovich H, Zecharia N, Atzmon N, Moshe Y, Schiller G (2013) Fire-free natural regeneration in water limited Pinus halepensis forests: a silvicultural approach. Eur J For Res 132: 679-690. https://doi.org/10.1007/s10342-013-0704-3

Outlaw WH, Zhan S, Riddle KA, Womble AK, Anderson LC, Outlaw EC, Thistle AB (2002) The jujube (Ziziphus jujuba Mill.), a multipurpose plant. Econ Bot 56:198-200. https://doi.org/10.1663/00130001(2002)056[0198:TJZJMA]2.0.CO;2

Owens NJ, Lund HG (2009) Forests and Forest Plants- Vol. II. EOLSS Publications

Pandey A, Singh R, Radhamani J, Bhandari DC (2010) Exploring the potential of Ziziphus nummularia (Burm. f.) Wight et Arn. from drier regions of India. Genet Resour Crop Evol 57:929-936. https://doi.org/10.1007/s10722-010-9566-4

Pareek OP (2001) Fruits for the future 2: Ber. International Centre for Underutilized Crops. University of Southampton, Southampton

Paz U (1979) Natural vegetation of Eretz Israel at the end of the Ottoman period. Teva Va'Aretz 12:49-52 (in Hebrew)

Paz-Kagan T, Zaady E, Karnieli A (2016) Transformation of shrublands to forests: the role of woody species as ecosystem engineers and landscape modulators. Forest Ecol Manag 361:257-268. https:// doi.org/10.1016/j.foreco.2015.11.021 
Pedlar JH, McKenney DW, Aubin I, Beardmore T, Beaulieu J, Iverson L, O'Neill GA, Winder RS, Ste-Marie C (2012) Placing forestry in the assisted migration debate. Bioscience 62:835-842. https://doi.org/ 10.1525/bio.2012.62.9.10

Pignatti S (1983) Human impact on the vegetation of the Mediterranean Basin. In: Holzner W, Werger MJA, Ikusima I (eds) Man's Impact on Vegetation. Junk, The Hague, pp 151-161

Reij C, Tappan G, Smale M (2009) Agroenvironmental transformation in the Sahel. Food Policy, IFPRI Discussion Paper http://www.ifpri. org/sites/default/files/publications/ifpridp00914.pdf

Reisman-Berman O, Rojo L, Berliner P (2011) Afforestation to combat desertification in arid zones requires a concerted endeavor. In: Birot Y, Gracia C, Palahí M (eds) Water for forests and people in the Mediterranean - a challenging balance. What science can tell us. European Forest Institute, pp 145-150

Rejmánek M (2014) Invasive trees and shrubs: where do they come from and what we should expect in the future? Biol Invasions 16:483498. https://doi.org/10.1007/s10530-013-0603-z

Reubens B, Moeremans C, Poesen J, Nyssen J, Tewoldeberhan S, Franzel S, Deckers J, Orwa C, Muys B (2011) Tree species selection for land rehabilitation in Ethiopia: from fragmented knowledge to an integrated multi-criteria decision approach. Agrofor Syst 82:303-330. https://doi.org/10.1007/s10457-011-9381-8

Ricciardi A, Simberloff D (2009) Assisted colonization is not a viable conservation strategy. Trends Ecol Evol 24:248-253. https://doi.org/ 10.1016/j.tree.2008.12.006

Richardson DM (1998) Forestry trees as invasive aliens. Conserv Biol 12: 18-26. https://doi.org/10.1111/j.1523-1739.1998.96392.x

Rosenzweig ML (2003) Reconciliation ecology and the future of species diversity. Oryx 37:194-205. https://doi.org/10.1017/ S0030605303000371

Rotenberg E, Yakir D (2010) Contribution of semi-arid forests to the climate system. Science 327:451-454. https://doi.org/10.1126/ science.1179998

Rudel TK, Schneider L, Uriarte M (2010) Forest transitions: an introduction. Land Use Policy 27:95-97. https://doi.org/10.1016/j. landusepol.2009.09.021

Sacande M, Berrahmouni N (2016) Community participation and ecological criteria for selecting species and restoring natural capital with native species in the Sahel. Restor Ecol 24:479-488

Saied AS, Gebauer J, Hammer K, Buerkert A (2008) Ziziphus spinachristi (L.) Willd.: a multipurpose fruit tree. Genet Resour Crop Evol 55:929-937. https://doi.org/10.1007/s10722-007-9299-1

Scherr SJ, McNeely JA (2008) Biodiversity conservation and agricultural sustainability: towards a new paradigm of 'ecoagriculture' landscapes. Philos Trans R Soc B 363:477-494. https://doi.org/10. 1098/rstb.2007.2165

Seddon PJ (2010) From reintroduction to assisted colonization: moving along the conservation translocation spectrum. Restor Ecol 18:796802. https://doi.org/10.1111/j.1526-100X.2010.00724.x

Sheffer E, Canham CD, Kigel J, Perevolotsky A (2014) An integrative analysis of the dynamics of landscape-and local-scale colonization of Mediterranean woodlands by Pinus halepensis. PLoS One 9: e90178

Singh K (1963) The ber in India. In: Fruit culture in India. ICAR, New Delhi

Singh IS, Awasthi OP, Singh RS, More TA, Meena SR (2012) Changes in soil properties under tree species. Indian J Agric Sci 82:146-151

Stanturf JA, Kant P, Barnekow Lillesø J-P, Mansourian S, Kleine M, Graudal L, Madsen P (2015) Forest landscape restoration as a key component of climate change mitigation and adaptation. IUFRO World Series Volume 34, Vienna

Stanturf J, Mansourian S, Kleine M (Eds.) (2017) Implementing forest landscape restoration, a practitioner's guide. International Union of
Forest Research Organizations, Special Programme for Development of Capacities (IUFRO-SPDC). Vienna, Austria

Sunderlin WD, Angelsen A, Belcher B, Burgers P, Nasi R, Santoso L, Wunder S (2005) Livelihoods, forests, and conservation in developing countries: an overview. World Dev 33:1383-1402. https://doi. org/10.1016/j.worlddev.2004.10.004

Tel-Zur N, Schneider B (2009) Floral biology of Ziziphus mauritiana (Rhamnaceae). Sex Plant Reprod 22:73-85. https://doi.org/10. 1007/s00497-009-0093-4

Tessema ZK, Belay EF (2017) Effect of tree species on understory vegetation, herbaceous biomass and soil nutrients in a semi-arid savanna of Ethiopia. J Arid Environ 139:76-84. https://doi.org/10.1016/j. jaridenv.2016.12.007

Thomas CD (2011) Translocation of species, climate change, and the end of trying to recreate past ecological communities. Trends Ecol Evol 26:216-221. https://doi.org/10.1016/j.tree.2011.02.006

UNEP (1992) World atlas of desertification. Edward Arnold, London

Valéry L, Fritz H, Lefeuvre JC (2013) Another call for the end of invasion biology. Oikos 122:1143-1146. https://doi.org/10.1111/j.16000706.2013.00445.x

Vashishtha BB (1997) Ziziphus for drylands - a perennial crop solving perennial problems. Agrofor Today 9:10-12

Verdeguer M, Blazquez MA, Boira H (2009) Phytotoxic effects of Lantana camara, Eucalyptus camaldulensis and Eriocephalus africanus essential oils in weeds of Mediterranean summer crops. Biochem Syst Ecol 37:362-369

Vilà M, Hulme PE (2017) Impact of biological invasions on ecosystem services. Springer, Cham. https://doi.org/10.1007/978-3-31945121-3

Vilà M, Vayreda J, Comas L, Ibanez JJ, Mata T, Obon B (2007) Species richness and wood production: a positive association in Mediterranean forests. Ecol Lett 10:241-250. https://doi.org/10. $1111 / j .1461-0248.2007 .01016 . x$

Wilson JRU et al (2011) Risk assessment, eradication, and biological control: global efforts to limit Australian acacia invasions. Divers Distrib 17:1030-1046. https://doi.org/10.1111/j.1472-4642.2011. 00815.x

Witt ABR (2017) Use of non-native species for poverty alleviation in developing economies. In: Vilà M, Hulme PE (eds) Impact of biological invasions on ecosystem services. Springer Cham, Switzerland. https://doi.org/10.1007/978-3-319-45121-3 19

Wolf DE, Takebayashi N, Rieseberg LH (2001) Predicting the risk of extinction through hybridization. Conserv Biol 15:1039-1053. https://doi.org/10.1046/j.1523-1739.2001.0150041039.x

Wolfersberger J, Delacote P, Garcia S (2015) An empirical analysis of forest transition and land-use change in developing countries. Ecol Econ 119:241-225. https://doi.org/10.1016/j.ecolecon.2015.08.018

Xu J, van Noordwijk M, He J, Kim KJ, Jo RS, Pak KG, Ho MH (2012) Participatory agroforestry development for restoring degraded sloping land in DPR Korea. Agrofor Syst 85:291-303. https://doi.org/ 10.1007/s10457-012-9501-0

Yirdaw E, Tigabu M, Monge Monge AA (2017) Rehabilitation of degraded dryland ecosystems-review. Silva Fennica 51: 1673.10.14214/sf.1673

Yosef G, Walko R, Avisar R, Tatarinov F, Rotenberg E, Yakir D (2018) Large-scale semi-arid afforestation can enhance precipitation and carbon sequestration potential. Sci Rep 8:996. https://doi.org/10. 1038/s41598-018-19265-6

Publisher's Note Springer Nature remains neutral with regard to jurisdictional claims in published maps and institutional affiliations. 